Int. J. Dev. Biol. 62: 441-451 (2018)

https://doi.org/10.1387/ijdb.170264JL

\title{
Revisiting the liver: from development to regeneration - what we ought to know!
}

\author{
JUDIT LÓPEZ-LUQUE*,1,2 and ISABEL FABREGAT*,1,2,3 \\ ${ }^{1}$ TGF- $\beta$ and Cancer Group, Oncobell Program, Bellvitge Biomedical Research Institute (IDIBELL), L'Hospitalet \\ de Llobregat, Barcelona, ${ }^{2}$ Oncology Program, CIBEREHD, National Biomedical Research Institute on Liver and \\ Gastrointestinal Diseases, Instituto de Salud Carlos III, Madrid, Spain and ${ }^{3}$ Department of Physiological Sciences, \\ Faculty of Medicine and Health Sciences, University of Barcelona, Spain
}

\begin{abstract}
The liver is structurally and functionally heterogeneous and complex, and it accomplishes crucial functions for the organism. Its most remarkable potential is its capacity to regenerate after injury in order to maintain whole body homeostasis and guarantee the survival of the individual. Under normal conditions, liver regeneration (LR) is attributed to adult hepatocytes, the main cells in the liver which are able to proliferate in response to different stimuli or injuries. Nevertheless, when liver injury is severe and/or hepatocytes are prevented from proliferation, liver stem/progenitor cells (LS/PCs) participate directing LR to maintain liver mass and functions. Different mechanisms have been shown to guide this second line of LR, such as intrahepatic and extrahepatic liver progenitor cells, as well as transdifferentiation processes between hepatocytes and other liver cells. For this reason, many efforts have been made to elucidate the specific molecular mechanisms which orchestrate this process; this in turn would improve the prognosis and treatment of liver diseases. In this review, we revisit the fascinating process of LR, also with a short overview about liver development, the process from which arises the concept of LS/PCs participating in LR, and very important nowadays when considering cell therapy and tissue bioengineering for the treatment of patients suffering from liver disease.
\end{abstract}

KEY WORDS: liver regeneration, hepatocyte, proliferation, liver stem/progenitor cell (LS/PC), growth factor

The liver has been shown to be a master central regulator of metabolism and detoxification. Thus, it uncovers a major role controlling part of body homeostasis, and liver failure would constitute a major health problem if this function is not properly carried out by the liver. Understanding this complex organ from its development during embryogenesis until the development of a liver disease will permit to pomp out with new targeted therapies and tissue engineering technologies to avoid liver failure or to recover liver functions crucial for life. More interesting for this review is the special ability of the liver to regenerate after toxic insults, tissue damage or tissue loss. Liver transplant is the only curative treatment for end-stage liver disease, which is the consequence of many chronic hepatic diseases. For instance, patients with hepatocellular carcinoma (HCC), the most often primary liver cancer and the second leading cause of cancer-related mortality worldwide, undergo surgical resection. However, remnant liver can exhibit poor regenerative capacity because of the underlying pathologies. These cases of a defective process explain the huge interest to better understand the machinery of liver regeneration to find new biomarkers that could predict the response and to develop improved therapeutic options for patients with liver diseases.

Abbreviations used in this paper: $\mathrm{BEC}$, biliary epithelial cell; ECM, extracellular matrix; EGF, Epidermal Growth Factor; ERK1/2, extracellular signal-regulated kinase 1 and 2; FGF, Fibroblast Growth Factor; HB-EGF, heparin binding EGF-like growth factor; HCC, hepatocellular carcinoma; HGF, hepatocyte growth factor; HSC, hepatic stellate cell; iPSC, induced pluripotent stem cell; KC, Kupffer cell; LR, liver regeneration; LS/PC, liver stem/progenitor cell; MAPK, mitogen-activated protein kinase; NF-ҚВ, nuclear factor-kappa B; $\mathrm{PHx}$, partial hepatectomy; PI3K, phosphatidylinositol-3-kinase; STAT3, signal transducer and activator of transcription 3; TGF- $\beta$, transforming growth factor-beta; TNF- $\alpha$, tumor necrosis factor-alpha.

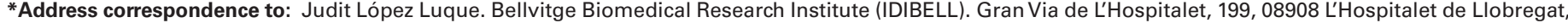

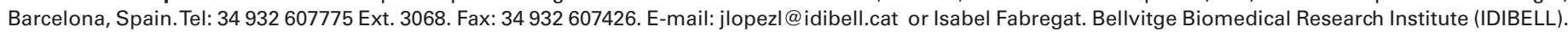
Gran Via de L'Hospitalet, 199. 08908 L'Hospitalet de Llobregat, Barcelona, Spain. Tel: 34932 607828. Fax: 34932 607426. E-mail: ifabregat@ idibell.cat
} 


\section{The origin: an overview of liver development}

To better understand the origin of this organ, it is worthy to start emphasizing its importance within the organism. The liver carries out numerous functions: glycogen storage, drug detoxification, plasma proteins secretion (Albumin (ALB), Transferrin and Apolipoproteins) and, importantly, the control of metabolism (glucose, fatty acids and triglycerides, cholesterol, urea and non-essential amino acids). Although hepatocytes account for about $80 \%$ of liver weight, other biologically important cell types are present: Biliary Epithelial Cells (BECs or cholangiocytes), Sinusoidal Endothelial Cells (SECs), Kupffer cells (KCs, resident liver macrophages), Pit cells (resident liver natural killer cells) and Hepatic Stellate Cells (HSCs) (Si-Tayeb et al., 2010).

Liver development in the embryo occurs in several stages (Fig. 1). In general terms, first, cells become "competent" and can restrict their fate. Then, competent cells subsequently become "committed" to a specific lineage, exhibiting morphological changes and expressing genes associated with cell commitment. Eventually, cells then "differentiate" along that lineage and are ultimately able to carry out the function of a terminally differentiated cell (Hata et al., 2007).

In mice, at early stages of development, epithelial cells of the foregut endoderm express the transcription factors (TFs) Foxa1/2 and Gata4-6, which permit to establish the "competence" of these cells to develop into the liver. At E8.5, this "competent" foregut endoderm interacts with the cardiac mesoderm and "commit" to induce hepatic fate in the ventral foregut endoderm. This is due to the coordinated signaling of Fibroblast Growth Factors (FGFs) from the cardiac mesoderm, and Bone Morphogenetic Proteins (BMPs) from the septum transversum mesenchyme (STM) that facilitate the "commitment" of "competent" foregut endoderm cells to become hepatoblasts. On the contrary, Wnt/ $\beta$-catenin signaling appears to repress liver fate (Rossi et al., 2001; Zorn, 2008; Kung et al., 2010; Si-Tayeb et al., 2010).

Shortly after hepatic specification (E8.5 to E9), the epithelium begins to express liver genes such as $A l b$, $\alpha$-fetoprotein (Afp), transthyretin (Ttr), Hnf1a and high expression of Cytokeratins (CKs) $8 / 18$ while low expression of CK-19. In addition, the ventral foregut

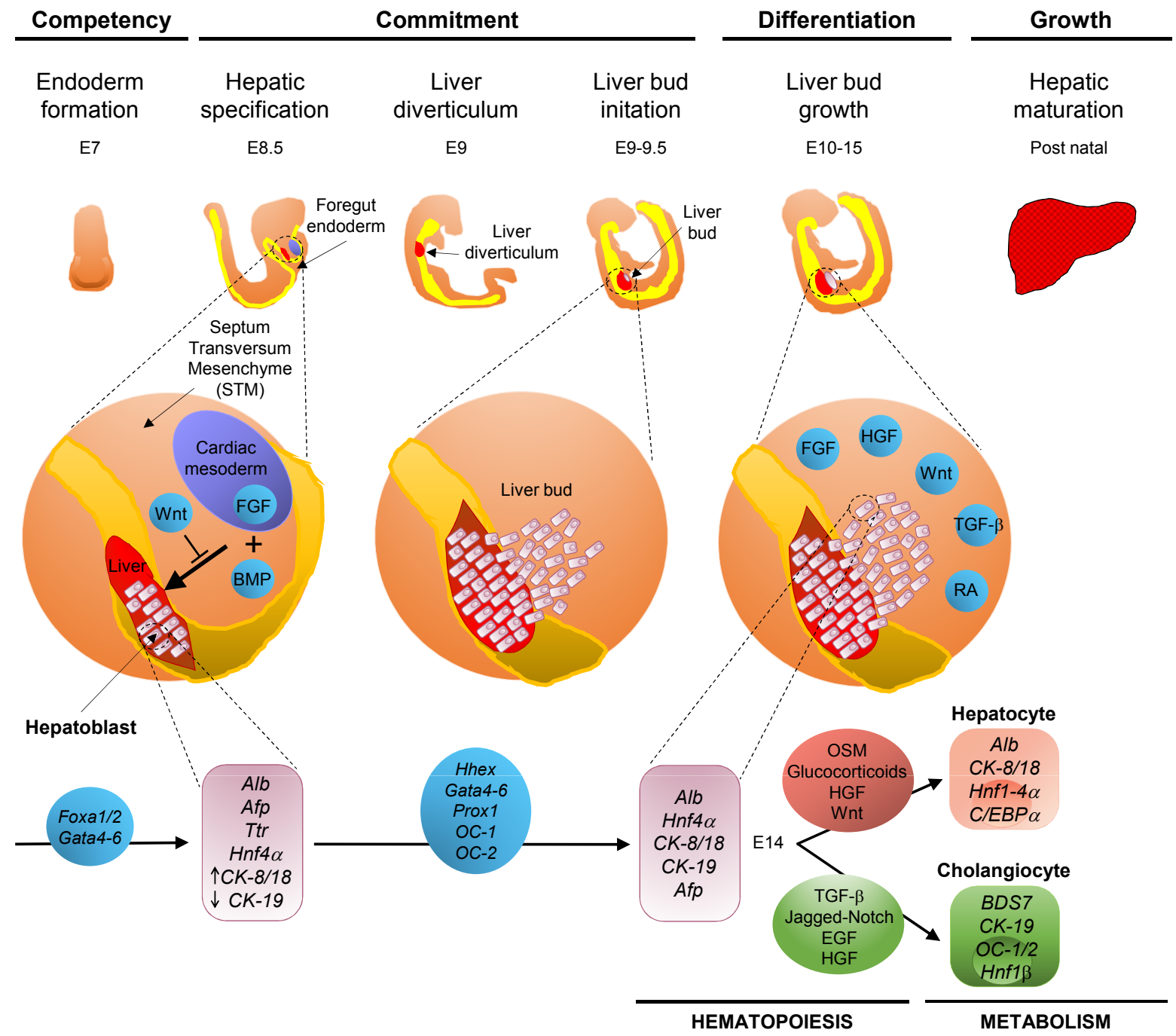

Fig. 1. Schematic overview of murine liver development. Stages of liver development are depicted, from a macroscopic and molecular point of view. Important factors are represented in each step. See text for further details. 
epithelium thickens finally forming the liver diverticulum. Between E9 to E9.5, the basal layer surrounding the hepatic endoderm breaks down and hepatoblasts delaminate from the epithelium, migrate to invade the adjacent STM and continue to proliferate and differentiate, to give rise the nascent liver bud. Several TFs and signals from endothelial cells are required for this process, such as Hhex, Gata4-6, Prox1, Onecut-1 (OC-1, also known as Hnf6) and Onecut-2 (OC-2) (Shafritz and Dabeva, 2002; Zorn, 2008; Kung et al., 2010; Si-Tayeb et al., 2010) (Fig. 1).

Between E10-15, the liver bud undergoes a period of accelerated growth and it is colonized by hematopoietic cells to become the major fetal hematopoietic organ. This is regulated by paracrine signals from STM and hepatic mesenchyme that promote proliferation and survival, including FGF, BMP, Hepatocyte Growth Factor (HGF), Transforming Growth Factor-beta (TGF- $\beta$ ), retinoic acid (RA) and Wnt, the last having the opposite effect than in previous stages. Around E14, one of the major stages occurs, when these bipotential hepatoblasts "differentiate" into hepatocytes and cholangiocytes. Initially, hepatoblasts express genes associated with both adult hepatocytes (Hnf4a, Al $\beta, C K-8 / 18)$ and BECs (CK-19), as well as fetal liver genes such as $A f p$. Those hepatoblasts residing next to portal veins adopt a specific structure together with the expression of BDS7, an increase in CK-19 and BEC TFs (OC-1/2 and HNF1 $\beta$ ), concomitant with downregulation of hepatic genes, finally becoming cholangiocytes. Among the mesenchyme signals involved, it is found TGF- $\beta$ and Jagged-Notch, which stimulates the expression of EGF, and together with HGF, participate in the differentiation towards a biliary epithelial phenotype. On the contrary, most hepatoblasts localized in the liver parenchyma differentiate into hepatocytes, acquiring characteristics of epithelial cells arranged in hepatic chords, and expressing $A / b$ and $C K-8 / 18$. Signals such as oncostatin M (OSM), glucocorticoids, HGF and Wnt promote hepatocyte differentiation, most of them through the regulation of the TFs C/EBPa, Hnф1a and Hnf4a. Maturation into hepatocytes and cholangiocytes continue until several weeks after birth. At this point, the organ's main function switches from hematopoiesis to metabolism, a capacity that dominates in the adult liver (Fig. 1) (Shafritz and Dabeva, 2002; Hata et al., 2007; Zorn, 2008; Kung et al., 2010; Gordillo et al., 2015).

\section{Liver regeneration: a well studied and still unknown process}

Although function, structure and development clearly differentiate the liver from other organs, the outstanding physiological characteristic that makes it special is the unique ability to fully regenerate. This process reminds the ancient greek myth of Prometheus, a titan who was bond to the mountain Caucasus by Zeus to get his liver eaten by an eagle daily, which regenerated during the nights, as a punishmentfor stealing the fire from gods and giving it to the mankind. Liver regeneration (LR) is the development of new hepatocytes during adulthood. Adult hepatocytes can replicate in a highly-regulated manner, regenerating the liver in response to surgical ablation, toxic injury, infections, exogenous stimulus, massive hepatocyte necrosis or apoptosis. In this section, we will try to give a vast overview of LR.

\section{Experimental models of liver regeneration (LR)}

Several models, considering animal species and methodologies, have been proposed for the study of LR. On the one hand, among the animal models traditionally used, rodents (rats and mice) are on the top, and almost all the studies and the current knowledge about LR come from them (Forbes and Newsome, 2016). However, new animal models have recently emerged, such as zebrafish. On the other hand, several methods have been described to induce loss of liver mass. It can be induced in pharmacological models by administering hepatotoxic chemicals (carbon tetrachloride $\left(\mathrm{CCl}_{4}\right)$, D-galactosamine or acetaminophen), bacterial particles (lipopolysaccharides (LPS)) and virus, among others. But there are also surgical models, and the most commonly and best-studied is the surgical procedure which removes $70 \%$ of the liver mass in rodents, known as 2/3 partial hepatectomy (PHx), and first described by Higgins and Anderson (Higgins and Anderson, 1931). Taking advantage of the multi-lobe structure of the liver, three of the five lobes (left lateral and median lobes) are removed by an easy surgical procedure, causing minimal tissue damage to the residual two lobes, which grow in size to restore the mass. The process, in rats and mice, is almost complete within 7-14 days after surgery.

\section{What is the reason for regeneration?}

The words "liver regeneration" could indicate that the liver is able to recover exactly the same disappeared lobules after resection. Nevertheless, this process is actually a "compensatory hyperplasia and hypertrophy" rather than a true restoration of the liver's original gross anatomy and architecture, which takes place in amphibians or Salamander in some parts of their bodies. Thus, during liver "regeneration" after PHx, the excised parts do not grow back. Instead, the remaining liver increases the mass to compensate for the lost tissue. Regarding terminology, hyperplasia would account for an increase in cell number, while hypertrophy refers to an increase in cell size. Although it has been generally accepted that hepatocytes undergo one to two rounds of cell division after $\mathrm{PHx}$, several studies point to the hypertrophy of hepatocytes during LR (Nagy et al., 2001; Minamishima et al., 2002; Miyaoka et al., 2012).

The reason of this special process is that liver functions are extremely essential for survival of the organism. Liver mass is maintained within a very narrow range in relation to the overall body mass, known as Liver Index (liver weight/body weight) x100 4-5\%). The liver-to-body-weight ratio must be maintained always at $100 \%$ of what it is necessary for body homeostasis, so the degree of grow is precisely controlled. If there is loss or gain of liver mass, such as after liver injury or pregnancy, respectively, compensatory proliferation or apoptosis of cells restore this ratio once the stimulus is removed (Riehle et al., 2011; Kang et al., 2012; Cienfuegos et al., 2014). This unique relationship is termed "hepatostat", and it has been well-defined and studied by many groups (Avila and Moschetta, 2015; Naugler et al., 2015) and recently extensively reviewed (Michalopoulos, 2017). Therefore, liver homeostasis is of huge importance for the organism to survive, and "hepatostat" permits to drive $L R$, to control its termination up to a right liver size, as well as to maintain the liver weight even under normal physiological conditions.

\section{First line of liver regeneration: hepatocytes as the main player}

It is now well accepted that two physiological forms of LR exist in response to different types of liver injury. The first one, in the case of PHx and some chemical liver injuries, is when liver mass is replaced by replication of existing hepatocytes, considered the quickest and most efficient way of LR. 
Mainly three networks mediate LR after PHx: cytokines, growth factors (GFs) and metabolic signals. Due to the high redundancy among their intracellular components, loss of an individual gene rarely leads to complete inhibition of LR. It proceeds along sequential and overlapping steps: an initiation "priming phase", rendering hepatocytes in a replicative competence state; a "proliferation/ progression phase", with the expansion of the entire hepatocyte population; and a "termination phase", where cell proliferation is suppressed to terminate regeneration at a defined point (Fig. 2). In addition, proliferation in the expansion phase requires a complex re-design of the liver, a remodeling process representing a "fourth phase".

\section{Priming phase}

Hepatocytes resting in proliferative quiescence $\left(G_{0}\right.$ phase) can rapidly and synchronously enter into cell cycle upon stimulation, undergoing one to two rounds of replication before returning to quiescence. However, in quiescent state, hepatocytes do not fully respond to GFs and need to be "primed" to enter the cell cycle $\left(G_{1}\right.$ phase). The cytokine network acts as the "priming phase", which occurs during the first $4 \mathrm{~h}$ and begins with the recognition of the Pathogen-Associated Molecular Patters (PAMPs) and the Damage-Associated Molecular Patterns (DAMPs) released from necrotic cells after tissue injury. They trigger the natural immune response, Tumor Necrosis Factor-alpha (TNF- $\alpha$ ) secretion by KCs, and interleukins IL-6, IL-1 $\beta$ and IL-8 synthesis. In brief, there is an initial activation of Nuclear Factor-kappa B (NF-KB) in KCs via TNF, lymphotoxin (from T cells), and/or complement components, with downstream secretion of IL-6. In turn, IL-6 binds its receptor on hepatocytes, leading to activation of the TF Signal Transducer and Activator of Transcription 3 (STAT3), among other pathways. Then, several immediate-early genes related to hepatocyte proliferation are induced within $2 \mathrm{~h}$, such as $c$-Fos, $c$-Jun and others (Michalopoulos, 2010; Riehle et al., 2011; Cienfuegos et al., 2014).

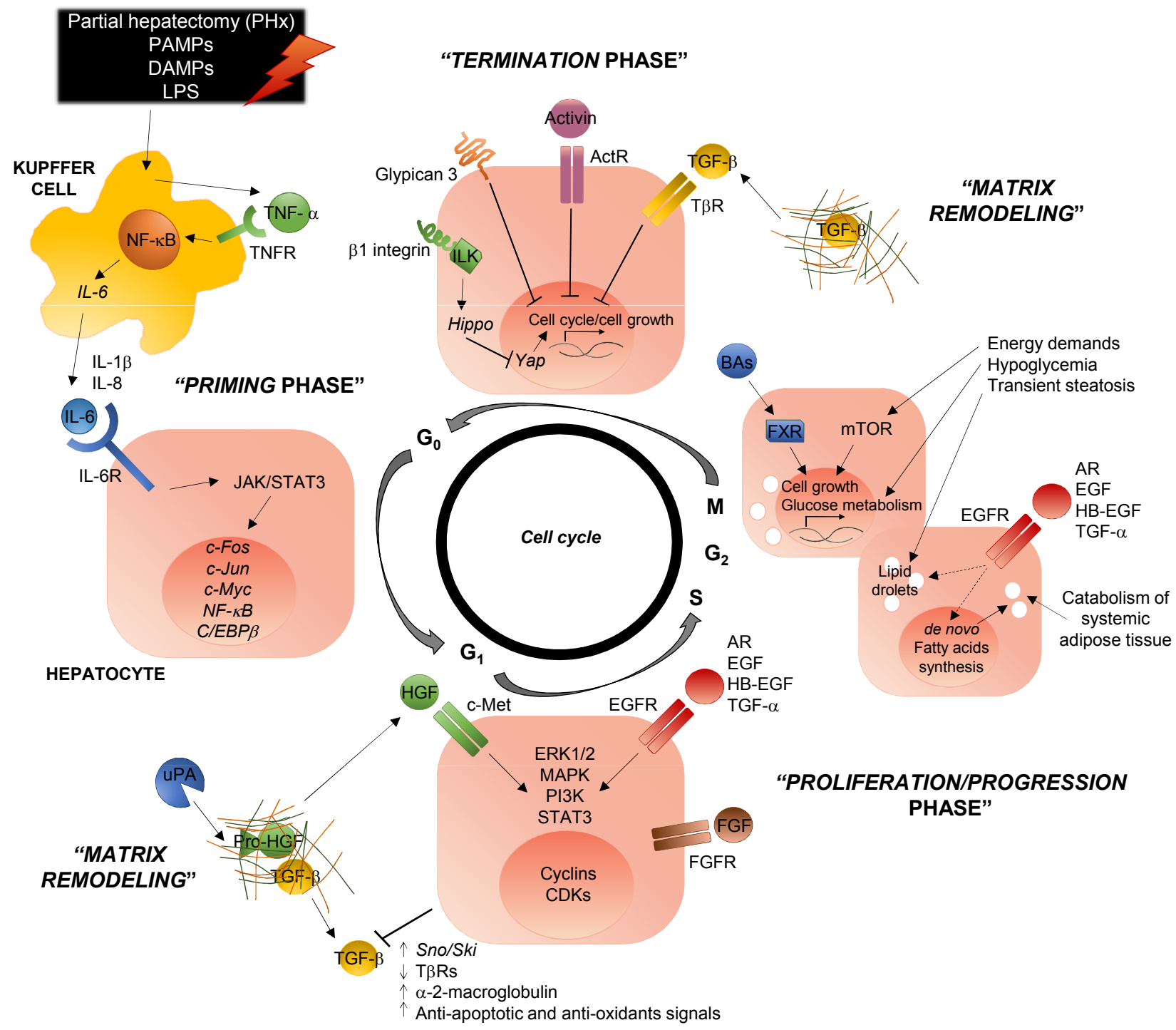

Fig. 2. Liver regeneration based on hepatocyte proliferation. Four phases are represented: Priming, Proliferation/progression, Termination and Matrix remodeling. Cytokines, growth factors and metabolic signals involved are also indicated. See text for further details. 
Although these cytokines are not directly mitogenic to hepatocytes, they are crucial to orchestrate and optimize the process: delayed LR was observed in TNFR1-/- mice due to inefficient activation of NF-KB (Yamada et al., 1998) and in mice lacking IL-6 due to loss of STAT3 activation (Cressman et al., 1996).

\section{Proliferation/progression phase}

After cytokines have triggered the $G_{0} / G_{1}$ transition, cell cycle progression is driven by GFs, which override the $G_{1}$ restriction point denominated "R", allowing hepatocytes enter S phase (DNA synthesis) 24 and $36 \mathrm{~h}$ post-PHx in rat and mouse, respectively. After, hepatocytes enter into mitosis 48h post-PHx. The mitogenic GFs Epidermal Growth Factor (EGF) and HGF activate their respective receptors, EGF Receptor (EGFR) and c-Met, stimulating hepatocytes progression through the cell cycle. Both are tyrosine kinase receptors, able to activate multiple intracellular signaling pathways. Among them, Mitogen-Activated Protein Kinase (MAPK), STAT3, Phosphatidylinositol-3-Kinase (PI3K)/Akt and Extracellular signal-Regulated Kinase 1 and 2 (ERK1/2) are the most important for LR, which in turn regulate a multitude of TFs including c-Jun, c-Fos, c-Myc, NF-kB, STAT3 and C/EBP $\beta$. Together with the induction of intermediate and early-delayed genes, such as cyclins and Cyclin Dependent Kinases (CDKs), they facilitate the transition to DNA synthesis and mitosis (Riehle et al., 2011; Kang et al., 2012; Mao et al., 2014; Cienfuegos et al., 2014). Finally, FGF family is also implicated in LR. Models expressing a dominant-negative mutant of FGF receptors (FGFR) signaling pathways presented delayed proliferation after PHx (Steiling et al., 2003). However, not all FGFRs play the same role: while loss of FGFR4 in mice did not affect the process (Yu et al., 2000), lacking FGFR1 and FGFR2 provoked an increased mortality showing a cytoprotective role of these receptors in regenerating liver (Böhm et al., 2010).

However, c-Met and EGFR are key factors in LR, which deserve a detailed discussion.

HGF/c-Met pathway - The receptor c-Met is activated by the mitogen HGF, produced by non-parenchymal cells, such as HSCs and SECs. It is produced by HSCs as single peptide (pro-HGF) and deposited in the extracellular matrix (ECM). Interestingly, one of the earliest changes is the increase in the activity of Urokinase-type Plasminogen Activator (UPA) within 1 min after PHx. UPA mediates the ECM remodeling that takes place soon after $\mathrm{PHx}$, involving metalloproteinases (MMPs) activation, such as MMP-2 and MMP-9 (Kim et al., 2000). Then after, there is the subsequent activation of this pro-HGF, finally releasing active HGF in the environment of hepatocytes as well as in blood circulation. In fact, uPA deficiency has been shown to retard LR (Shimizu et al., 2001).

EGFR pathway - This receptor is activated through different sources: in an autocrine manner by Amphiregulin (AR) and Transforming Growth Factor-alpha (TGF- $\alpha$ ); by Heparin Binding EGF-like growth factor (HB-EGF) derived from KCs and SECs; and by EGF, secreted from salivary glands and Brunner's glands in the duodenum (Berasain and Avila, 2014). EGFR ligands have different but often overlapping functions during LR. Thus, TGF- $\alpha$ null mice have no deficiency during LR (Russell et al., 1996), whereas the removal of the submandibular glands in mice (source of EGF) or AR and HB-EGF knock-out mice promoted an impaired or delayed LR (Noguchi et al., 1991; Berasain et al., 2005; Mitchell et al., 2005).

It seems that both receptors have unique and potentially overlapping functions. Many studies have been done to better understand their role during LR. First studies were based on mice lacking c-Met in the liver. On the one hand, inducible deletion of the c-Met gene in the liver caused a defective exit of hepatocytes from quiescence and a delay in cell cycle entry after PHx (Borowiak et al., 2004). On the other hand, deletion of the c-Met gene in hepatocytes in a non-inducible manner showed the inability of these animals to survive the procedure showing severe necrosis (Huh et al., 2004). Subsequent and complementary studies based on RNAinterference (shRNA) against c-Met and HGF in rats supported the previous works (Paranjpe et al., 2007). Moreover, a more recent work also showed a regenerative defect in hepatocyte-specific Met KO mice. Specifically, after PHx, Met-deficient hepatocytes showed a block in early/mid $G_{2}$ phase and consequently, a failure in $G_{2} / M$ gene expression program. Similar alterations were found in primary hepatocytes from unchallenged Met KO mice, which could be partially reversed by treating the cells with EGF (Factor et al., 2010). All these works confirmed the importance of c-Met in LR. Regarding EGFR pathway, to overcome the problem of redundancy among ligands, models lacking EGFR in hepatocytes were generated. The first study based on the genetic loss of EGFR in mice showed higher rates of mortality post-PHx. However, apoptosis was not increased, suggesting that activation of the EGFR pathway was not directly related with survival signals for hepatocytes. Moreover, delayed and reduced hepatocyte proliferation was observed in the remaining animals, although complete regeneration occurred, so EGFR would be important but not essential for LR (Natarajan et al., 2007). Another study using interference RNA in rats confirmed the critical role of this pathway, observing decreased DNA replication after $\mathrm{PHx}$, concomitant with an up-regulation of Met and other ErbB members and, finally, liver restoration occurred (Paranjpe et al., 2010). In contrast to these two studies, animals treated with a neutralizing antibody against EGFR did not present altered LR (Van Buren et al., 2008). More recently, a different study also using EGFR null mice showed delayed cell cycle progression and proliferation after $\mathrm{PHx}$, but the overall effect on liver regeneration was relatively minimal. Additionally, after $\mathrm{CCl}_{4}$-induced injury only the Met-KO, but not the EGFR-KO, displayed enhanced necrosis and delayed LR, effects that were more prominent in the EGFRMet double KOs, suggesting that EGFR, and at a greater extent Met, may partially compensate each other (Scheving et al., 2015). Regarding this issue, our group has recently developed a novel transgenic mouse model expressing a hepatocyte-specific truncated form of human EGFR, lacking the catalytic domain, thus acting as a negative dominant mutant (aEGFR) allowing definition of its tyrosine kinase-dependent functions. These animals displayed lower and delayed proliferation as well as lower activation of proliferative early signals after $\mathrm{PHx}$, demonstrating a critical role during the initial phases of LR. Moreover, it correlated with an overactivation of the TGF- $\beta$ pathway, and subsequent amplification of its cytostatic effects. Nevertheless, NEGFR were able to fully regenerate the liver by overactivating compensatory signals, such as c-Met pathway (López-Luque et al., 2016). Regarding this issue, a very recent work has demonstrated that only the combined elimination of Met and the inhibition of the EGFR signaling pathway completely abolishes LR. They state that both pathways separately control many non-overlapping critical points, and inhibition of only one of them had distinct alterations in different signaling pathways, allowing for compensation when only one of the signals is blocked (Paranjpe et al., 2016). All these works emphasize the requirement 
of simultaneous co-activation of parallel signaling pathways for full mitogenic signaling and efficient LR.

It is important to mention that, after $\mathrm{PHx}$, metabolic alterations occur in the remnant liver. The liver must continue regulating systemic energy levels while meeting its own demands for nucleotide and protein synthesis needed for cell division. Thus, translation is the control point that integrates nutrient levels with mitogenic signals and most proteins involved are downstream of mammalian target of rapamycin (mTOR). Almost a complete loss of hepatocyte DNA replication was observed in S6 KO mice after $\mathrm{PHx}$ (Volarevic et al., 2000). Importantly, changes in lipid and glucose metabolism are observed. A regenerative transient steatosis is evident during LR after PHx at early stages, which is necessary for LR (Huang and Rudnick, 2014) and concomitant with upregulation of genes related to the adipogenic program (Shteyer et al., 2004). Increased de novo hepatic fatty acid production and catabolism of systemic adipose tissue might be the main sources of the lipid that accumulates in the regenerating liver. It is required to meet the increased energy demand for rapid cell proliferation and essential for the enhanced biosynthesis of membrane phospholipids (Rudnick and Davidson, 2012). Disruption of hepatic adipogenesis and lipid accumulation is associated with impaired or inefficient LR following PHx (Shteyer et al., 2004; Kohjima et al., 2013). Interestingly, EGFR plays a role in the regulation of liver and plasma lipid levels in adult male mice (Scheving et al., 2014). In addition, recently it has been shown that EGFR, but not the HGF/c-Met pathway, is required for fat accumulation and properly regulation of key enzymes related to the de novo lipid synthesis during LR, revealing a new function for EGFR kinase activity which is not overlapping with the HGF/cMet pathway (López-Luque et al., 2016; Paranjpe et al., 2016). Regarding glucose metabolism, mice develop hypoglycemia soon after PHx, showing insulin decreased levels. To compensate this, many TFs are activated upregulating glucose metabolism. Studies postponing this hypoglycemic response delayed LR (Huang et al., 2016). Finally, bile acid metabolism is also altered, increasing twice their amounts per liver mass without showing hepatotoxicity (Csanaky et al., 2009).

\section{Termination phase}

The initial burst of hepatocyte proliferative activity is followed by secondary waves of mitosis until original liver mass is restored. However, growth must be finished to control liver size and homeostais, although the precise mechanisms of a proper termination are still very poorly understood, and even controversial. Generally, when the regenerating liver reaches certain size, several factors promote proliferation arrest. Surprisingly, many of them are also present in the first stages of LR. It has been proposed that these factors would act as a "brake", controlling the speed of proliferation and the terminal point of the process, and even ensuring the right direction, preventing oncogenesis. An extensive review focused in the termination phase has been recently published (Liu and Chen, 2017). For this reason, this phase is as important as the previous ones, and more studies should be performed to decipher its molecular mechanisms. It is known that it involves multiple factors, including TGF- $\beta$ family (TGF- $\beta 1$, activins), IL-1, and tumor suppressor genes (p53, p21) (Michalopoulos, 2010).

TGF- $\beta 1$ is a known suppressor of hepatocyte proliferation and inducer of apoptosis. Then, it would be easy to think a role for it at the end of LR. Surprisingly, its expression increases rapidly after
$\mathrm{PHx}$, and levels are maintained until termination of the process (Braun et al., 1988). In addition, TGF- $\beta$ plasma levels rise together with HGF, suggesting that the cytokine is released after the remodeling of the ECM, where it is bound to decorin (Dudás et al., 2001). However, responsiveness to this factor declines transiently in the regenerating liver. TGF- $\beta$ inhibitory effects are surpassed by different mechanisms: TGF- $\beta$ receptors downregulation (Chari et al., 1995), increasing the transcriptional repressors SnoN and Ski (Macias-Silva etal., 2002), as well as being removed and inactivated through binding $\alpha-2$-macroglobulin in the circulation (LaMarre et al., 1991). Moreover, regenerating hepatocytes showed a reduced response to TGF- $\beta$ cytostatic and cytotoxic effects, through upregulation of anti-apoptotic and anti-oxidant signals (Herrera et al., 2004). Interestingly, mice lacking the type II TGF- $\beta$ receptor in hepatocytes presented an increased proliferative response after $\mathrm{PHx}$, but hyperproliferation was transient and normal regeneration was achieved (Romero-Gallo et al., 2005). Thus, although initially it was supposed that TGF- $\beta$ could play a relevant role in mediating termination of LR, more recent results indicate that it is not necessary during this stage. Higher and accelerated DNA synthesis peak after PHx was found in a Tgfbr2 knockout animal model. Nevertheless, similarly to the previous mentioned work, a normal ending of LR occurred, associated with increased compensatory inhibitory signals, particularly Activin A (Oe et al., 2004). Interestingly, TGF- $\beta$ could play an essential role in the first stages of LR, as transgenic mice expressing EGFR form presented an overactivation of the TGF- $\beta$ pathway leading to a delayed regeneration (López-Luque et al., 2016). Thus, a perfect spatio-temporal orchestration of TGF- $\beta$ signaling during the process is required, although it is still unclear. As the NADPH oxidase NOX4 is known to mediate TGF- $\beta$-induced apoptosis (Carmona-Cuenca et al., 2008) and to inhibit hepatocyte proliferation (Crosas-Molist et al., 2014), it would be a perfect candidate for mediating some of the TGF- $\beta$ suppressor actions during LR. Interestingly, NOX4 has been shown to be also regulated during $\mathrm{LR}$, decreasing its levels soon after $\mathrm{PHx}$ and recuperating them at the end of the process (Crosas-Molist et al., 2014). This should be an additional mechanism to avoid TGF- $\beta$ suppressor effects during the early liver regenerative process.

Among other players linked to the termination phase, the Integrin Linked Kinase (ILK) would play a role. ILK is under the plasma membrane associated with $\beta 1$ integrin, suppressing hepatocyte growth. ILK hepatoespecific KO animals acquire hepatomegaly and enhanced hepatocyte proliferation, presenting an impaired termination of the process (Gkretsi etal., 2008). On the otherhand, Glypican 3, a GPI-linked protein on hepatocytes plasma membrane, has been shown to suppress proliferation after $\mathrm{PHx}$ when overexpressed in transgenic animals (Liu et al., 2010). In addition, these animals also presented decreased expression of Yap (Yes-associated protein), controlled by the Hippo pathway, and which has been considered a central player controlling cell size and, finally, liver hepatostat.

Thus, a proper balance of all these signals during the different phases might be a good determinant of the efficacy of LR.

\section{Second line of liver regeneration: the time for stem/progenitor cells}

When the liver is damaged with specific chemicals, when injury is severe, or when mature hepatocytes are prevented from proliferation, the contribution of liver stem/progenitor cells (LS/PCs) is crucial for LR success (Fig. 3). 
As it has been mentioned, during liver development, both hepatocytes and BECs originate from the common precursor named hepatoblast. It is suggested that combined hepatocyte loss concomitant with impaired hepatocyte proliferation is necessary to activate these LS/PCs during LR. This has been observed in models combining $\mathrm{PHx}$ with chemical inhibition of hepatocyte proliferation using 2-acetylaminofluorene (2-AAF) or retrorsine in rats, or a choline-deficient diet in mice (Liu et al., 2016). LS/PCs reside in the transition region between the canaliculi and intrahepatic bile ducts, named Canal of Hering. It has been postulated that LS/PCs can be characterized by a positive staining for BEC markers, but also by the appearance of LS/PCs (named "oval cells" in rodents and "ductular structures" in humans) throughout the parenchyma when there is a liver repair process, often forming clusters of duct-like and/ or cord-like structures (Itoh, 2016). Therefore, in an elegant review, Itoh propose a model for homeostatic maintenance and LR, where the scenario starts with hepatocyte proliferation upon acute or mild hepatocyte injury. However, if injury is severe or chronic, a novel epithelial cell population identified by Font-Burgada et al., namely the periportal Hybrid hepatocytes (HybHPs), is activated, located in the portal triads of healthy livers and expressing low amounts of Sox9 and other bile-duct-enriched genes (Font-Burgada et al., 2015). If they are selectively damaged, then a recently found population of "unipotent stem cell-like" hepatocytes with selfrenewing abilities adjacent to the central vein (generally diploid and expressing Axin2, the canonical Wnt signaling target gene) can participate (Wang et al., 2015). Finally, if all these cells fail, it is when LS/PCs in the biliary compartment become activated to re-establish the parenchyma (Itoh, 2016) (Fig. 3).

The response of LS/PCs includes activation, proliferation, migration and differentiation, finally leading to hepatocytes or cholangiocytes. Parenchymal and non-parenchymal cells in the liver, the ECM, GFs and signaling pathways participate contributing to LS/PCs niche during LR. Regarding the crosstalk with other cells, for instance, it is found that HSCs participate in the first stages of LR producing HGF, promoting proliferation in LS/PCs. However, at the end of the process, high levels of TGF- $\beta$ produced also by HSCs suppressed DNAsynthesis in the same cells, revealing a dual role for HSCs in LS/PCs-mediated proliferation (Chen et al., 2012). Regarding the ECM, its remodeling by MMPs and the multiple factors found in it have been reported to stimulate

Fig. 3. Liver regeneration based on stem/progenitor cells. Intrahepatic and extrahepatic liver progenitor cells participate in regenerating the liver when hepatocytes are prevented from proliferating or when injury is severe. See text for further details.
LS/PCs proliferation. They comprise inflammatory cytokines (IL-6, TNF- $\alpha$, Stromal Derived Factor (SDF-1), TNF-like weak inducer of apoptosis (TWEAK), Stem Cell Factor (SCF), etc.), regulatory proteins (such as MERLIN acting on EGFR), or other paracrine messengers from neighboring mesenchymal cells (HGF, FGF and TGF- $\alpha / \beta)$. Specifically, HGF, EGF, TGF- $\alpha$ and SCF stimulate LS/ PCs proliferation. On the contrary, TWEAK/Fibronectin 14 would participate in the activation, and SDF-1/CXC receptor 4 (SDF-1/ CXCR4) axis in the migration of these cells (Liu et al., 2016). Among all these factors, as during LR from pre-existing hepatocytes, cMet and EGFR pathways are essential for regeneration from LS/ PCs. In this sense, Met signaling is essential for survival of oval cells in vitro, as its deletion increases sensitivity to TGF- $\beta$-induced apoptosis, through the activation of the PI3K signaling pathway (del Castillo et al., 2008a; Martínez-Palacián et al., 2013). Moreover, c-Met pathway promotes oval cell migration in vitro, activity that also involves PI3K signaling (Suárez-Causado et al., 2015). In vivo, lack of c-Met has profound effects on the LS/PCs-driven regeneration, including impairment in cell proliferation, migration and differentiation into hepatocytes (Ishikawa et al., 2012). Regarding EGFR, it also promotes oval cell proliferation and survival, although it is dispensable for c-Met-mediated proliferation and survival of these cells, functioning independently one from each other (Martínez-Palacián et al., 2012). Interestingly, while c-Met is important for hepatocytic differentiation, EGFR promotes cholangiocyte specification concomitantly suppressing hepatocyte commitment inducing Notch1 (Kitade et al., 2013). Therefore, it is very common to find that these factors play different, and sometime opposite, roles on hepatocytes and progenitors cells. Finally, all the above-mentioned GFs and cytokines trigger mul-

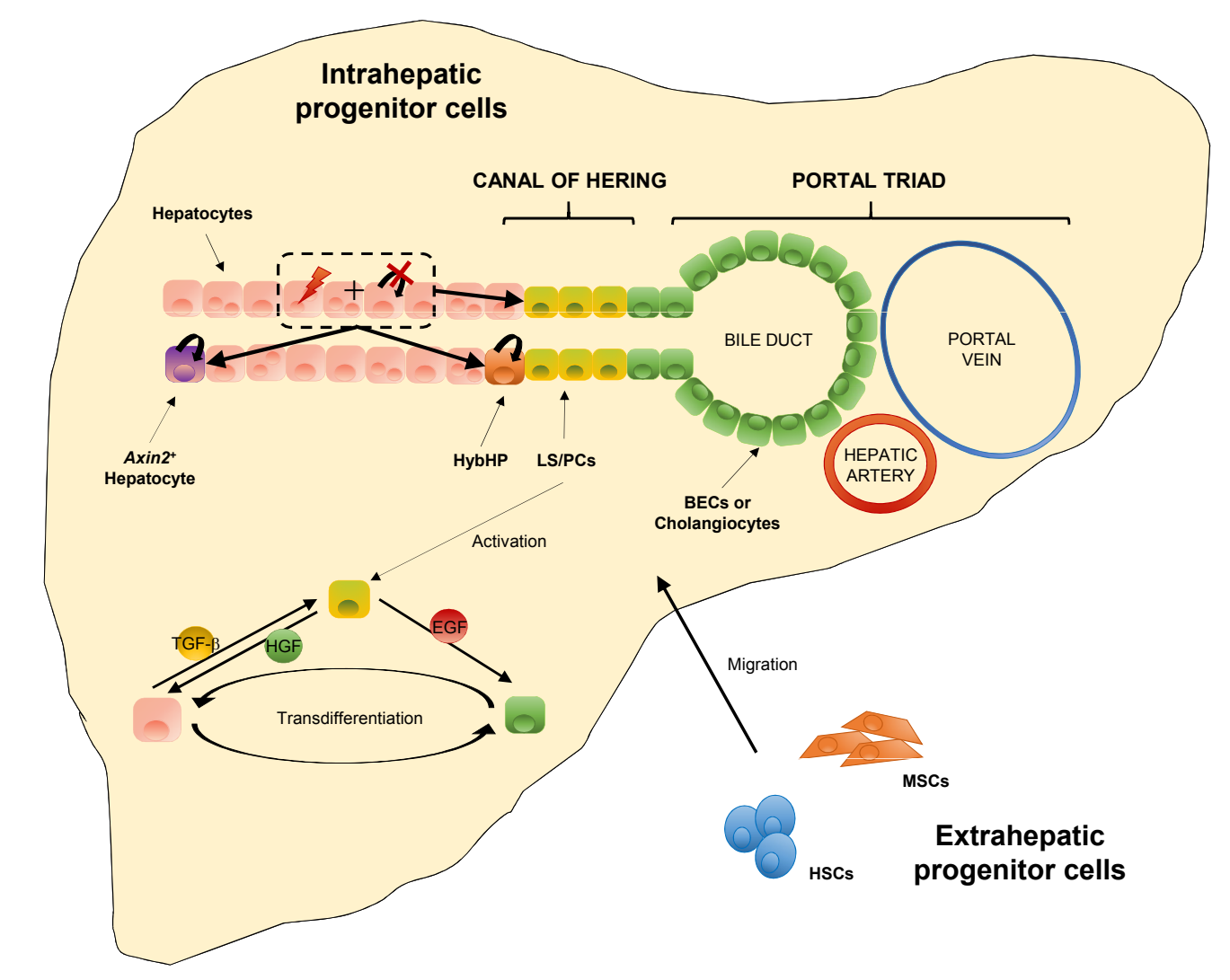


tiple signaling pathways. For instance, activation of NF-kB and STAT3 in rat oval cells is required for their activation, expansion and differentiation (Sánchez et al., 2004). Finally, Wnt and Notch pathways participate with opposite roles: while the former direct LS/PCs towards the hepatocytic fate, the second promotes their differentiation towards the biliary lineage (Boulter et al., 2012). Of special relevance is also the implication of inflammatory signals and cells, known as "inflammatory niche", on the regeneration by progenitor cells. Although some of them have been mentioned just above, it is worthy to point out that many of them play contrary roles in the regeneration from mature hepatocytes and the one carried out by progenitor cells. For instance, while IFN- $\gamma$ signaling appears to have a negative impact on LR by mature cells, the effects of this inflammatory cytokine on the progenitor cell compartment appear very different (Bisgaard et al., 1999). However, what it is completely obvious is that the inflammatory microenvironment regulates liver progenitor cells expansion and fate, which has been extensively reviewed by others (SantoniRugiu et al., 2005).

However, the huge controversial discussion comes up with the hypothesis that hepatocytes and cholangiocytes would be liver progenitors cells per se when undergoing transdifferentiation from one cell type to the other, acting as "facultative stem cells" (Michalopoulos and Khan, 2015). Many different studies have been focused on the possibility that cholangiocytes become LS/ PCs to rescue hepatocytes. While most of them confirmed this hypothesis (Golding et al., 1995; Huch et al., 2015; Raven et al., 2017), other groups did not (Schaub et al., 2014; Yanger et al., 2014). Almost all these studies prove that some cholangiocytes express hepatocyte-associated TFs, then proliferate as LS/PCs and, finally, become hepatocytes. Less controversy is found about the capacity of hepatocytes transdifferentiating directly to cholangiocytes. This has been observed in rats after biliary injury, without evidence of formation of LS/PCs (Michalopoulos et al., 2005) (Fig. 3). However, various works point to the capacity of hepatocytes to acquire also stem cell properties. Thus, after TGF$\beta$ treatment, the subpopulation of rat fetal hepatocytes $(\mathrm{FH})$ that survive to its apoptotic effects undergo epithelial-to-mesenchymal transition (EMT), expressing high levels of mesenchymal markers and lacking epithelial and differentiation ones, concomitant with expression of progenitor markers. Moreover, they acquire resistance to TGF- $\beta$-induced apoptosis (Valdés et al., 2002; del Castillo et al., 2006). Their isolation and characterization demonstrated that they behave as liver progenitors, supporting the hypothesis that hepatocytes can function as facultative liver stem cells and that TGF- $\beta$ might play an essential role in this transdifferentiation process (del Castillo et al., 2008b). Importantly, this response was observe in human hepatocytes (Caja et al., 2011), reaffirming TGF- $\beta$ as an inducer of EMT and promoting the acquisition of a stem-like phenotype. Interestingly, this was a reversible process, where mesenchymal stem-like cells were able to re-differentiate to hepatocytes, fact that opens feasible possibilities for human liver diseases.

Nevertheless, not only resident LS/PCs play a role in this second line of LR. Nowadays, there is a consensus that also stem cells from extrahepatic sites, in particular the bone marrow (BM), can participate and contribute to LR (Petersen et al., 1999; Theise et al., 2000) although with low efficiency. Hematopoietic Stem Cells (HSCs) and Mesenchymal Stem Cells (MSCs) are among the most well defined ones, migrating to the injured liver through circulation to regenerate the organ (Fig. 3). The differentiation of MSCs into MSCs-derived hepatocytes (MDHs) arises with 3 important shifts: morphologically (changing from a fibroblast-morphology to a polygonal-epithelial shape), phenotipically (regarding several TFs) and functional (acquiring the ability for glycogen storage, detoxification and lipid metabolism, within others). Nevertheless, the mechanisms of MSCs and HSCs transdifferentiation to hepatocytes are controversial. In fact, cell fusion with hepatocytes is an alternative way by which both cell types can achieve the plasticity required to develop into hepatocytes (Vassilopoulos et al., 2003; Wang et al., 2003; Quintana-Bustamante et al., 2006; Liu et al., 2015).

Finally, considering both mechanisms of the liver to regenerate, it seems obvious that progenitor cells can be a very reasonable option and an attractive alternative to organ transplantation due to several benefits: they can be expanded in culture without losing bidirectional differentiation potential, and an autologous transplant after LS/PCs isolation from a patient would obviate the need for immunosuppression (Liu et al., 2016). Several alternative candidates to liver transplants have been proposed based on the progenitor cells concept, including the above-mentioned MSCs and, more recently, induced pluripotent stem cells (iPSCs).

The attractive ability to derive pluripotent cells from adult human tissues opens new opportunities in research and, importantly, in therapy. This direct reprogramming towards producing pluripotent stem cells was first achieved and published in 2007 (Takahashi et al., 2007; Yu et al., 2007). With this in mind, several works have developed the technology in the liver field. Thus, iPSCs-derived hepatocytes proved to have functional and proliferative capabilities needed for LR in vivo in mice (Espejel et al., 2010), and this could be induced modeling the embryonic liver development conditions (Sancho-Bru et al., 2011). Later, a great achievement was carried out by Takebe et al., with the formation of vascularized and functional human liver after transplantation of liver buds created in vitro derived form iPSCs (Takebe et al., 2013). This represents a huge step forward in the field to cure human liver pathologies. Nevertheless, the liver is a very complex organ from a structural point of view and highly heterogeneous with different cell types participating to develop its function. For this reason, there is currently no technology available to grow a newly liver that accomplishes all the characteristics to the same extent as an original one. Liver engineering tries to solve these problems, through the repopulation of a decellularized liver stroma scaffold with hepatocytes and other liver cell types, or through 3D-bioprinting technology with biological materials (Kholodenko and Yarygin, 2017). However, these very promising approaches have not yet been completely successful as they are very challenging, although they clearly open a very encouraging landscape.

\section{Future perspectives}

LR is required to guarantee the liver function during processes of chronic liver diseases. Furthermore, liver resection is the most common approach used by clinicians in secondary/metastatic lesions in the liver. For this reason, it is indispensable to continue focusing on the molecular mechanisms that orchestrate LR to predict and even improve the response of each patient to the surgery. Deciphering the enigmas of LR might also contribute to 
the development of artificial functional livers to be used in patients with liver failure.

\section{Acknowledgments}

We want to apologize for all the works that have not been represented in this review due to a matter of space. This work was supported by grants from: 1) Ministry of Economy and Competitiveness-MINECO, Spain (cofounded by FEDER funds/European Regional Development Fund - a way to build Europe): Contract grant numbers: SAF2015-64149-R and ISCIII-RTICC RD12-0036-0029; 2) AGAUR-Generalitat de Catalunya: Contract grant number 2014SGR0334. The CIBEREHD, National Biomedical Research Institute on Liver and Gastrointestinal Diseases, is funded by the Instituto de Salud Carlos III, Spain.

\section{References}

AVILA, M.A., and MOSCHETTA, A. (2015). The FXR-FGF19 Gut-Liver Axis as a Novel "Hepatostat." Gastroenterology 149: 537-540.

BERASAIN, C., and AVILA, M.A. (2014). The EGFR signalling system in the liver: from hepatoprotection to hepatocarcinogenesis. J Gastroenterol 49: 9-23.

BERASAIN, C., GARCíA-TREVIJANO, E.R., CASTILLO, J., ERROBA, E., LEE, D.C., PRIETO, J., and AVILA, M.A. (2005). Amphiregulin: an early trigger of liver regeneration in mice. Gastroenterology 128: 424-432.

BISGAARD, H.C., MÜLLER, S., NAGY, P., RASMUSSEN, L.J., andTHORGEIRSSON, S.S. (1999). Modulation of the gene network connected to interferon-gamma in liver regeneration from oval cells. Am J Pathol 155: 1075-1085.

BÖHM, F., SPEICHER, T., HELLERBRAND, C., DICKSON, C., PARTANEN, J.M., ORNITZ, D.M., and WERNER, S. (2010). FGF receptors 1 and 2 control chemically induced injury and compound detoxification in regenerating livers of mice. Gastroenterology 139: 1385-1396.

BOROWIAK, M., GARRATT, A.N., WÜSTEFELD, T., STREHLE, M., TRAUTWEIN, C., and BIRCHMEIER, C. (2004). Met provides essential signals for liver regeneration. Proc Natl Acad Sci USA 101: 10608-10613.

BOULTER, L., GOVAERE, O., BIRD, T.G., RADULESCU, S., RAMACHANDRAN, P., PELLICORO, A., RIDGWAY, R.A., SEO, S.S., SPEE, B., VAN ROOIJEN, N., et al., (2012). Macrophage-derived Wnt opposes Notch signaling to specify hepatic progenitor cell fate in chronic liver disease. Nat Med 18: 572-579.

BRAUN, L., MEAD, J.E., PANZICA, M., MIKUMO, R., BELL, G.I., and FAUSTO, N. (1988). Transforming growth factor beta mRNA increases during liver regeneration: a possible paracrine mechanism of growth regulation. Proc Natl Acad Sci USA 85: 1539-1543.

CAJA, L., BERTRAN, E., CAMPBELL, J., FAUSTO, N., and FABREGAT, I. (2011). The transforming growth factor-beta (TGF- $\beta$ ) mediates acquisition of a mesenchymal stem cell-like phenotype in human liver cells. J Cell Physiol 226: 1214-1223.

CARMONA-CUENCA, I., RONCERO, C., SANCHO, P., CAJA, L., FAUSTO, N., FERNÁNDEZ, M., and FABREGAT, I. (2008). Upregulation of the NADPH oxidase NOX4 by TGF-beta in hepatocytes is required for its pro-apoptotic activity. $J$ Hepatol 49: 965-976.

DEL CASTILLO, G., MURILLO, M.M., ALVAREZ-BARRIENTOS, A., BERTRAN, E., FERNÁNDEZ, M., SÁNCHEZ, A., and FABREGAT, I. (2006). Autocrine production of TGF-beta confers resistance to apoptosis after an epithelial-mesenchymal transition process in hepatocytes: Role of EGF receptor ligands. Exp Cell Res 312: 2860-2871.

DEL CASTILLO, G., FACTOR, V.M., FERNÁNDEZ, M., ALVAREZ-BARRIENTOS, A., FABREGAT, I., THORGEIRSSON, S.S., and SÁNCHEZ, A. (2008a). Deletion of the Met tyrosine kinase in liver progenitor oval cells increases sensitivity to apoptosis in vitro. Am J Pathol 172: 1238-1247.

DELCASTILLO, G., ALVAREZ-BARRIENTOS,A., CARMONA-CUENCA, I., FERNÁNDEZ, M., SÁNCHEZ, A., and FABREGAT, I. (2008b). Isolation and characterization of a putative liver progenitor population after treatment of fetal rat hepatocytes with TGF-beta. J Cell Physiol 215: 846-855.

CHARI, R.S., PRICE, D.T., SUE, S.R., MEYERS, W.C., and JIRTLE, R.L. (1995). Down-regulation of transforming growth factor beta receptor type I, II, and III during liver regeneration. Am J Surg 169: 126-131; discussion 131-132.
CHEN, L., ZHANG, W., ZHOU, Q., YANG, H., LIANG, H., ZHANG, B., LONG, X. and CHEN, X. (2012). HSCs play a distinct role in different phases of oval cellmediated liver regeneration. Cell Biochem Funct 30: 588-596.

CIENFUEGOS, J.A., ROTELLAR, F., BAIXAULI, J., MARTÍNEZ-REGUEIRA, F., PARDO, F., and HERNÁNDEZ-LIZOÁIN, J.L. (2014). Liver regeneration--the best kept secret. A model of tissue injury response. Rev Esp Enferm Dig 106: 171-194.

CRESSMAN, D.E., GREENBAUM, L.E., DEANGELIS, R.A., CILIBERTO, G., FURTH, E.E., POLI, V., and TAUB, R. (1996). Liver failure and defective hepatocyte regeneration in interleukin-6-deficient mice. Science 274: 1379-1383.

CROSAS-MOLIST, E., BERTRAN, E., SANCHO, P., LÓPEZ-LUQUE, J., FERNANDO, J., SÁNCHEZ, A., FERNÁNDEZ, M., NAVARRO, E., and FABREGAT, I. (2014) The NADPH oxidase NOX4 inhibits hepatocyte proliferation and liver cancer progression. Free Radic Biol Med 69: 338-347.

CSANAKY, I.L., ALEKSUNES, L.M., TANAKA, Y., and KLAASSEN, C.D. (2009). Role of hepatic transporters in prevention of bile acid toxicity after partial hepatectomy in mice. Am J Physiol Gastrointest Liver Physiol 297: G419-433.

DUDÁS, J., KOVALSZKY, I., GALLAI, M., NAGY, J.O., SCHAFF, Z., KNITTEL, T., MEHDE, M., NEUBAUER, K., SZALAY, F., and RAMADORI, G. (2001). Expression of decorin, transforming growth factor-beta 1, tissue inhibitor metalloproteinase 1 and 2, and type IV collagenases in chronic hepatitis. Am J Clin Pathol 115:725-735.

ESPEJEL, S., ROLL, G.R., MCLAUGHLIN, K.J., LEE, A.Y., ZHANG, J.Y., LAIRD, D.J., OKITA, K., YAMANAKA, S., and WILLENBRING, H. (2010). Induced pluripotent stem cell-derived hepatocytes have the functional and proliferative capabilities needed for liver regeneration in mice. J Clin Invest 120: 3120-3126.

FACTOR, V.M., SEO, D., ISHIKAWA, T., KAPOSI-NOVAK, P., MARQUARDT, J.U. ANDERSEN, J.B., CONNER, E.A., and THORGEIRSSON, S.S. (2010). Loss of C-Met disrupts gene expression program required for $\mathrm{G} 2 / \mathrm{M}$ progression during liver regeneration in mice. PloS One 5: e12739.

FONT-BURGADA, J., SHALAPOUR, S., RAMASWAMY, S., HSUEH, B., ROSSELL, D., UMEMURA, A., TANIGUCHI, K., NAKAGAWA, H., VALASEK, M.A., YE, L., et al., (2015). Hybrid Periportal Hepatocytes Regenerate the Injured Liver without Giving Rise to Cancer. Cell 162: 766-779.

FORBES, S.J., and NEWSOME, P.N. (2016). Liver regeneration - mechanisms and models to clinical application. Nat Rev Gastroenterol Hepatol 13: 473-485.

GKRETSI, V., APTE, U., MARS, W.M., BOWEN, W.C., LUO, J.-H., YANG, Y., YU, Y.P., ORR, A., ST-ARNAUD, R., DEDHAR, S., et al., (2008). Liver-specific ablation of integrin-linked kinase in mice results in abnormal histology, enhanced cell proliferation, and hepatomegaly. Hepatology 48: 1932-1941.

GOLDING, M., SARRAF, C.E., LALANI, E.N., ANILKUMAR, T.V., EDWARDS, R.J. NAGY, P., THORGEIRSSON, S.S., and ALISON, M.R. (1995). Oval cell differentiation into hepatocytes in the acetylaminofluorene-treated regenerating rat liver. Hepatology 22: 1243-1253.

GORDILLO, M., EVANS, T., and GOUON-EVANS, V. (2015). Orchestrating liver development. Development 142: 2094-2108.

HATA, S., NAMAE, M., and NISHINA, H. (2007). Liver development and regeneration: from laboratory study to clinical therapy. Dev Growth Differ 49: 163-170.

HERRERA, B., ALVAREZ, A.M., BELTRÁN, J., VALDÉS, F., FABREGAT, I., and FERNÁNDEZ, M. (2004). Resistance to TGF-beta-induced apoptosis in regenerating hepatocytes. J Cell Physiol 201: 385-392.

HIGGINS, G.M., and ANDERSON, R.M. (1931). Experimental pathology of the liver. I. Restoration of the liver of the white rat following partial surgical removal. Arch Pathol 12: 186-202.

HUANG, J., and RUDNICK, D.A. (2014). Elucidating the metabolic regulation of liver regeneration. Am J Pathol 184: 309-321.

HUANG, J., SCHRIEFER, A.E., CLIFTEN, P.F., DIETZEN, D., KULKARNI, S., SING S., MONGA, S.P.S., and RUDNICK, D.A. (2016). Postponing the Hypoglycemic Response to Partial Hepatectomy Delays Mouse Liver Regeneration. Am J Pathol 186: 587-599.

HUCH, M., GEHART, H., VANBOXTEL, R., HAMER, K., BLOKZIJL, F., VERSTEGEN M.M.A., ELLIS, E., VAN WENUM, M., FUCHS, S.A., DE LIGT, J., et al., (2015) Long-term culture of genome-stable bipotent stem cells from adult human liver. Cell 160: 299-312.

HUH, C.-G., FACTOR, V.M., SÁNCHEZ, A., UCHIDA, K., CONNER, E.A., andTHORGEIRSSON, S.S. (2004). Hepatocyte growth factor/c-met signaling pathway is required for efficient liver regeneration and repair. Proc Natl Acad Sci USA 101: 
4477-4482.

ISHIKAWA, T., FACTOR, V.M., MARQUARDT, J.U., RAGGI, C., SEO, D., KITADE, M., CONNER, E.A., and THORGEIRSSON, S.S. (2012). Hepatocyte growth factor/c-met signaling is required for stem-cell-mediated liver regeneration in mice. Hepatology 55: 1215-1226.

ITOH, T. (2016). Stem/progenitor cells in liver regeneration. Hepatology64: 663-668.

KANG, L.-I., MARS, W.M., and MICHALOPOULOS, G.K. (2012). Signals and cells involved in regulating liver regeneration. Cells 1: 1261-1292.

KHOLODENKO, I.V., and YARYGIN, K.N. (2017). Cellular Mechanisms of Liver Regeneration and Cell-Based Therapies of Liver Diseases. Biomed Res Int 2017: 8910821.

KIM, T.H., MARS, W.M., STOLZ, D.B., and MICHALOPOULOS, G.K. (2000). Expression and activation of pro-MMP-2 and pro-MMP-9 during rat liver regeneration. Hepatology 31: 75-82.

KITADE, M., FACTOR, V.M., ANDERSEN, J.B., TOMOKUNI, A., KAJI, K., AKITA, H., HOLCZBAUER, A., SEO, D., MARQUARDT, J.U., CONNER, E.A., et al., (2013). Specific fate decisions in adult hepatic progenitor cells driven by MET and EGFR signaling. Genes Dev 27: 1706-1717.

KOHJIMA, M., TSAI, T.-H., TACKETT, B.C., THEVANANTHER, S., LI, L., CHANG, B.H.-J., and CHAN, L. (2013). Delayed liver regeneration after partial hepatectomy in adipose differentiation related protein-null mice. J Hepatol 59: 1246-1254.

KUNG, J.W.C., CURRIE, I.S., FORBES, S.J., and ROSS, J.A. (2010). Liver development, regeneration, and carcinogenesis. J Biomed Biotechnol 2010: 984248.

LAMARRE, J., HAYES, M.A., WOLLENBERG, G.K., HUSSAINI, I., HALL, S.W., and GONIAS, S.L. (1991). An alpha 2-macroglobulin receptor-dependent mechanism for the plasma clearance of transforming growth factor-beta 1 in mice. J Clin Invest 87: 39-44.

LIU, M., and CHEN, P. (2017). Proliferation-inhibiting pathways in liver regeneration (Review). Mol Med Rep 16: 23-35.

LIU, B., BELL, A.W., PARANJPE, S., BOWEN, W.C., KHILLAN, J.S., LUO, J.-H., MARS, W.M., and MICHALOPOULOS, G.K. (2010). Suppression of liver regeneration and hepatocyte proliferation in hepatocyte-targeted glypican 3 transgenic mice. Hepatology 52: 1060-1067.

LIU, W., SONG, F., REN, L., GUO, W., WANG, T., FENG, Y., TANG, L., and LI, K. (2015). The multiple functional roles of mesenchymal stem cells in participating in treating liver diseases. J Cell Mol Med 19: 511-520.

LIU, W.-H., REN, L.-N., WANG, T., NAVARRO-ALVAREZ, N., and TANG, L.-J. (2016). The Involving Roles of Intrahepatic and Extrahepatic Stem/Progenitor Cells (SPCs) to Liver Regeneration. Int J Biol Sci 12: 954-963.

LÓPEZ-LUQUE, J., CABALLERO-DÍAZ, D., MARTINEZ-PALACIÁN, A., RONCERO, C., MORENO-CÀCERES, J., GARCÍA-BRAVO, M., GRUESO, E., FERNÁNDEZ, A., CROSAS-MOLIST, E., GARCÍA-ÁLVARO, M., et al., (2016). Dissecting the role of epidermal growth factor receptor catalytic activity during liver regeneration and hepatocarcinogenesis. Hepatology 63: 604-619.

MACIAS-SILVA, M., LI, W., LEU, J.I., CRISSEY, M.A.S., and TAUB, R. (2002). Up-regulated transcriptional repressors SnoN and Ski bind Smad proteins to antagonize transforming growth factor-beta signals during liver regeneration. $J$ Biol Chem 277: 28483-28490.

MAO, S.A., GLORIOSO, J.M., and NYBERG, S.L. (2014). Liver regeneration. TransI Res 163: 352-362.

MARTíNEZ-PALACIÁN, A., DEL CASTILLO, G., HERRERA, B., FERNÁNDEZ, M., RONCERO, C., FABREGAT, I., and SÁNCHEZ, A. (2012). EGFR is dispensable for c-Met-mediated proliferation and survival activities in mouse adult liver oval cells. Cell Signal 24: 505-513.

MARTÍNEZ-PALACIÁN, A., DEL CASTILLO, G., SUÁREZ-CAUSADO, A., GARCÍAÁLVARO, M., DE MORENA-FRUTOS, D., FERNÁNDEZ, M., RONCERO, C., FABREGAT, I., HERRERA, B., and SÁNCHEZ, A. (2013). Mouse hepatic oval cells require Met-dependent $\mathrm{PI} 3 \mathrm{~K}$ to impair TGF- $\beta$-induced oxidative stress and apoptosis. PloS One 8: e53108.

MICHALOPOULOS, G.K. (2010). Liver regeneration after partial hepatectomy: critical analysis of mechanistic dilemmas. Am J Pathol 176: 2-13.

MICHALOPOULOS, G.K., and KHAN, Z. (2015). Liver Stem Cells: Experimental Findings and Implications for Human Liver Disease. Gastroenterology 149: 876-882.

MICHALOPOULOS, G.K., BARUA, L., and BOWEN, W.C. (2005). Transdifferentiation of rat hepatocytes into biliary cells after bile duct ligation and toxic biliary injury. Hepatology 41: 535-544.
MINAMISHIMA, Y.A., NAKAYAMA, K., and NAKAYAMA, K.-I. (2002). Recovery of liver mass without proliferation of hepatocytes after partial hepatectomy in Skp2deficient mice. Cancer Res 62: 995-999.

MITCHELL, C., NIVISON, M., JACKSON, L.F., FOX, R., LEE, D.C., CAMPBELL, J.S. and FAUSTO, N. (2005). Heparin-binding epidermal growth factor-like growth factor links hepatocyte priming with cell cycle progression during liver regeneration. J Biol Chem 280: 2562-2568.

MIYAOKA, Y., EBATO, K., KATO, H., ARAKAWA, S., SHIMIZU, S., and MIYAJIMA A. (2012). Hypertrophy and Unconventional Cell Division of Hepatocytes Underlie Liver Regeneration. Curr Biol 22: 1166-1175.

NAGY, P., TERAMOTO, T., FACTOR, V.M., SANCHEZ, A., SCHNUR, J., PAKU, S., and THORGEIRSSON, S.S. (2001). Reconstitution of liver mass via cellular hypertrophy in the rat. Hepatology 33: 339-345.

NATARAJAN, A., WAGNER, B., and SIBILIA, M. (2007). The EGF receptor is required for efficient liver regeneration. Proc Natl Acad Sci USA 104: 17081-17086.

NAUGLER, W.E., TARLOW, B.D., FEDOROV, L.M., TAYLOR, M., PELZ, C., LI, B., DARNELL, J., and GROMPE, M. (2015). Fibroblast Growth Factor Signaling Controls Liver Size in Mice With Humanized Livers. Gastroenterology 149: 728-740.

NOGUCHI, S., OHBA, Y., and OKA, T. (1991). Influence of epidermal growth factor on liver regeneration after partial hepatectomy in mice. J Endocrinol 128: 425-431.

OE, S., LEMMER, E.R., CONNER, E.A., FACTOR, V.M., LEVÉEN, P., LARSSON, J., KARLSSON, S., and THORGEIRSSON, S.S. (2004). Intact signaling by transforming growth factor beta is not required for termination of liver regeneration in mice. Hepatology 40: 1098-1105.

PARANJPE, S., BOWEN, W.C., BELL, A.W., NEJAK-BOWEN, K., LUO, J.-H., and MICHALOPOULOS, G.K. (2007). Cell cycle effects resulting from inhibition of hepatocyte growth factor and its receptor c-Met in regenerating rat livers by RNA interference. Hepatology 45: 1471-1477.

PARANJPE, S., BOWEN, W.C., TSENG, G.C., LUO, J.-H., ORR, A., and MICHALOPOULOS, G.K. (2010). RNA interference against hepatic epidermal growth factor receptor has suppressive effects on liver regeneration in rats. Am J Pathol 176: 2669-2681.

PARANJPE, S., BOWEN, W.C., MARS, W.M., ORR, A., HAYNES, M.M., DEFRANCES, M.C., LIU, S., TSENG, G.C., TSAGIANNI, A., and MICHALOPOULOS, G.K. (2016). Combined systemic elimination of MET and EGFR signaling completely abolishes liver regeneration and leads to liver decompensation. Hepatology64: 1711-1724.

PETERSEN, B.E., BOWEN, W.C., PATRENE, K.D., MARS, W.M., SULLIVAN, A.K., MURASE, N., BOGGS, S.S., GREENBERGER, J.S., and GOFF, J.P. (1999). Bone marrow as a potential source of hepatic oval cells. Science 284: 1168-1170.

QUINTANA-BUSTAMANTE, O., ALVAREZ-BARRIENTOS, A., KOFMAN, A.V., FABREGAT, I., BUEREN, J.A., THEISE, N.D., and SEGOVIA, J.C. (2006). Hematopoietic mobilization in mice increases the presence of bone marrow-derived hepatocytes via in vivo cell fusion. Hepatology 43: 108-116.

RAVEN, A., LU, W.-Y., MAN, T.Y., FERREIRA-GONZALEZ, S., O'DUIBHIR, E., DWYER, B.J., THOMSON, J.P., MEEHAN, R.R., BOGORAD, R., KOTELIANSKY, V., et al., (2017). Cholangiocytes act as facultative liver stem cells during impaired hepatocyte regeneration. Nature 547: 350-354.

RIEHLE, K.J., DAN, Y.Y., CAMPBELL, J.S., and FAUSTO, N. (2011). New concepts in liver regeneration. J Gastroenterol Hepatol 26: 203-212.

ROMERO-GALLO, J., SOZMEN, E.G., CHYTIL, A., RUSSELL, W.E., WHITEHEAD, R., PARKS, W.T., HOLDREN, M.S., HER, M.F., GAUTAM, S., MAGNUSON, M., et al., (2005). Inactivation of TGF-beta signaling in hepatocytes results in an increased proliferative response after partial hepatectomy. Oncogene24:3028-3041.

ROSSI, J.M., DUNN, N.R., HOGAN, B.L., and ZARET, K.S. (2001). Distinct mesodermal signals, including BMPs from the septum transversum mesenchyme, are required in combination for hepatogenesis from the endoderm. Genes Dev 15: 1998-2009.

RUDNICK, D.A., and DAVIDSON, N.O. (2012). Functional Relationships between Lipid Metabolism and Liver Regeneration. Int J Hepatol 2012: 549241.

RUSSELL, W.E., KAUFMANN, W.K., SITARIC, S., LUETTEKE, N.C., and LEE, D.C. (1996). Liver regeneration and hepatocarcinogenesis in transforming growth factor-alpha-targeted mice. Mol Carcinog 15: 183-189.

SÁNCHEZ, A., FACTOR, V.M., SCHROEDER, I.S., NAGY, P., and THORGEIRSSON, S.S. (2004). Activation of NF-kappaB and STAT3 in rat oval cells during 2-acetylaminofluorene/partial hepatectomy-induced liver regeneration. Hepatology 39: 376-385.

SANCHO-BRU, P., ROELANDT, P., NARAIN, N., PAUWELYN, K., NOTELAERS, 
T., SHIMIZU, T., OTT, M., and VERFAILLIE, C. (2011). Directed differentiation of murine-induced pluripotent stem cells to functional hepatocyte-like cells. $J$ Hepatol 54: 98-107.

SANTONI-RUGIU, E., JELNES, P., THORGEIRSSON, S.S., and BISGAARD, H.C. (2005). Progenitor cells in liver regeneration: molecular responses controlling their activation and expansion. APMIS 113: 876-902.

SCHAUB, J.R., MALATO, Y., GORMOND, C., and WILLENBRING, H. (2014). Evidence against a stem cell origin of new hepatocytes in a common mouse model of chronic liver injury. Cell Rep 8: 933-939.

SCHEVING, L.A., ZHANG, X., GARCIA, O.A., WANG, R.F., STEVENSON, M.C., THREADGILL, D.W., and RUSSELL, W.E. (2014). Epidermal growth factor receptor plays a role in the regulation of liver and plasma lipid levels in adult male mice. Am J Physiol Gastrointest Liver Physiol 306: G370-381.

SCHEVING, L.A., ZHANG, X., STEVENSON, M.C., THREADGILL, D.W., and RUSSELL, W.E. (2015). Loss of hepatocyte EGFR has no effect alone but exacerbates carbon tetrachloride-induced liver injury and impairs regeneration in hepatocyte Met-deficient mice. Am J Physiol Gastrointest Liver Physiol 308: G364-G377.

SHAFRITZ, D.A., and DABEVA, M.D. (2002). Liver stem cells and model systems for liver repopulation. J Hepatol 36: 552-564.

SHIMIZU, M., HARA, A., OKUNO, M., MATSUNO, H., OKADA, K., UESHIMA, S. MATSUO, O., NIWA, M., AKITA, K., YAMADA, Y., et al., (2001). Mechanism of retarded liver regeneration in plasminogen activator-deficient mice: impaired activation of hepatocyte growth factor after Fas-mediated massive hepatic apoptosis. Hepatology 33: 569-576.

SHTEYER, E., LIAO, Y., MUGLIA, L.J., HRUZ, P.W., and RUDNICK, D.A. (2004). Disruption of hepatic adipogenesis is associated with impaired liver regeneration in mice. Hepatology 40: 1322-1332.

SI-TAYEB, K., LEMAIGRE, F.P., and DUNCAN, S.A. (2010). Organogenesis and development of the liver. Dev Cell 18: 175-189.

STEILING, H., WÜSTEFELD, T., BUGNON, P., BRAUCHLE, M., FÄSSLER, R., TEUPSER, D., THIERY, J., GORDON, J.I., TRAUTWEIN, C., and WERNER, S. (2003). Fibroblast growth factor receptor signalling is crucial for liver homeostasis and regeneration. Oncogene 22: 4380-4388.

SUÁREZ-CAUSADO, A., CABALLERO-DÍAZ, D., BERTRÁN, E., RONCERO, C., ADDANTE, A., GARCÍA-ÁLVARO, M., FERNÁNDEZ, M., HERRERA, B., PORRAS, A., FABREGAT, I., et al., (2015). HGF/c-Met signaling promotes liver progenitor cell migration and invasion by an epithelial-mesenchymal transition-independent, phosphatidyl inositol-3 kinase-dependent pathway in an in vitro model. Biochim Biophys Acta 1853: 2453-2463.

TAKAHASHI, K., TANABE, K., OHNUKI, M., NARITA, M., ICHISAKA, T., TOMODA, K., and YAMANAKA, S. (2007). Induction of pluripotent stem cells from adult human fibroblasts by defined factors. Cell 131: 861-872.
TAKEBE, T., SEKINE, K., ENOMURA, M., KOIKE, H., KIMURA, M., OGAERI, T., ZHANG, R.-R., UENO, Y., ZHENG, Y.-W., KOIKE, N., et al., (2013). Vascularized and functional human liver from an iPSC-derived organ bud transplant. Nature 499: 481-484.

THEISE, N.D., BADVE, S., SAXENA, R., HENEGARIU, O., SELL, S., CRAWFORD, J.M., and KRAUSE, D.S. (2000). Derivation of hepatocytes from bone marrow cells in mice after radiation-induced myeloablation. Hepatology 31: 235-240.

VALDÉS, F., ALVAREZ, A.M., LOCASCIO, A., VEGA, S., HERRERA, B., FERNÁNDEZ, M., BENITO, M., NIETO, M.A., and FABREGAT, I. (2002). The epithelia mesenchymal transition confers resistance to the apoptotic effects of transforming growth factor Beta in fetal rat hepatocytes. Mol Cancer Res 1: 68-78.

VAN BUREN, G., YANG, A.D., DALLAS, N.A., GRAY, M.J., LIM, S.J., XIA, L., FAN F., SOMCIO, R., WU, Y., HICKLIN, D.J., et al., (2008). Effect of molecular therapeutics on liver regeneration in a murine model. J Clin Oncol 26: 1836-1842.

VASSILOPOULOS, G., WANG, P.-R., and RUSSELL, D.W. (2003). Transplanted bone marrow regenerates liver by cell fusion. Nature 422: 901-904.

VOLAREVIC, S., STEWART, M.J., LEDERMANN, B., ZILBERMAN, F., TERRAC CIANO, L., MONTINI, E., GROMPE, M., KOZMA, S.C., and THOMAS, G. (2000) Proliferation, but not growth, blocked by conditional deletion of $40 \mathrm{~S}$ ribosomal protein S6. Science 288: 2045-2047.

WANG, B., ZHAO, L., FISH, M., LOGAN, C.Y., and NUSSE, R. (2015). Self-renewing diploid Axin2(+) cells fuel homeostatic renewal of the liver. Nature 524: 180-185.

WANG, X., WILLENBRING, H., AKKARI, Y., TORIMARU, Y., FOSTER, M., ALDHALIMY, M., LAGASSE, E., FINEGOLD, M., OLSON, S., and GROMPE, M. (2003). Cell fusion is the principal source of bone-marrow-derived hepatocytes. Nature 422: 897-901.

YAMADA, Y., WEBBER, E.M., KIRILLOVA, I., PESCHON, J.J., and FAUSTO, N. (1998) Analysis of liver regeneration in mice lacking type 1 or type 2 tumor necrosis facto receptor: requirement for type 1 but not type 2 receptor. Hepatology 28: 959-970.

YANGER, K., KNIGIN, D., ZONG, Y., MAGGS, L., GU, G., AKIYAMA, H., PIKARSKY, E., and STANGER, B.Z. (2014). Adult hepatocytes are generated by self-duplication rather than stem cell differentiation. Cell Stem Cell 15: 340-349.

YU, C., WANG, F., KAN, M., JIN, C., JONES, R.B., WEINSTEIN, M., DENG, C.X. and MCKEEHAN, W.L. (2000). Elevated cholesterol metabolism and bile acid synthesis in mice lacking membrane tyrosine kinase receptor FGFR4. J Biol Chem 275: 15482-15489.

YU, J., VODYANIK, M.A., SMUGA-OTTO, K., ANTOSIEWICZ-BOURGET, J., FRANE J.L., TIAN, S., NIE, J., JONSDOTTIR, G.A., RUOTTI, V., STEWART, R., et al., (2007). Induced pluripotent stem cell lines derived from human somatic cells. Science 318: 1917-1920.

ZORN, A.M. (2008). Liver development. In StemBook (Cambridge (MA)). 


\section{Further Related Reading, published previously in the Int. J. Dev. Biol.}

Amphioxus regeneration: evolutionary and biomedical implications

Ildikó M.L. Somorjai

Int. J. Dev. Biol. (2017) 61: 689-696

Zfyve9a regulates the proliferation of hepatic cells during zebrafish embryogenesis Nian Liu, Zhuo Li, Duanqing Pei and Xiaodong Shu

Int. J. Dev. Biol. (2013) 57: 773-778

https://doi.org/10.1387/ijdb.130065xs

Differentiation of human embryonic stem cells into hepatocytes in 2D and 3D culture systems in vitro Hossein Baharvand, Seyed M. Hashemi, Saeid Kazemi Ashtiani and Ali Farrokhi

Int. J. Dev. Biol. (2006) 50: 645-652

https://doi.org/10.1387/ijdb.052072hb

Quantitative gene expression profiling reveals a fetal hepatic phenotype of murine ES-derived hepatocytes Andrea Jochheim, Tina Hillemann, Gabriela Kania, Jennifer Scharf, Masoumeh Attaran, Michael P Manns, Anna M Wobus and Michael Ott Int. J. Dev. Biol. (2004) 48: 23-29

http://www.intjdevbiol.com/web/paper/15005571

The role of p53 in vivo during skeletal muscle post-natal development and regeneration: studies in p53 knockout mice

Jason D White, Collins Rachel, Royce Vermeulen, Marilyn Davies and Miranda D Grounds Int. J. Dev. Biol. (2002) 46: 577-582

http://www.intjdevbiol.com/web/paper/12141446

Alcohol consumption during pregnancy alters glycoconjugates, galactosyltransferase activity and beta-COP proteins in the Golgi apparatus of hepatocytes in developing liver J M Seguí, R Guasch, I Azorin, C Guerri and J Renau-Piqueras

Int. J. Dev. Biol. (1996) 40: S285-S286

http://www.intjdevbiol.com/web/paper/9087800

The role of determined stem-cells in the cellular lineage of hepatocellular carcinoma S Sell

Int. J. Dev. Biol. (1993) 37: 189-201

http://www.intjdevbiol.com/web/paper/8389577

5 yr ISI Impact Factor $(2016)=2.421$
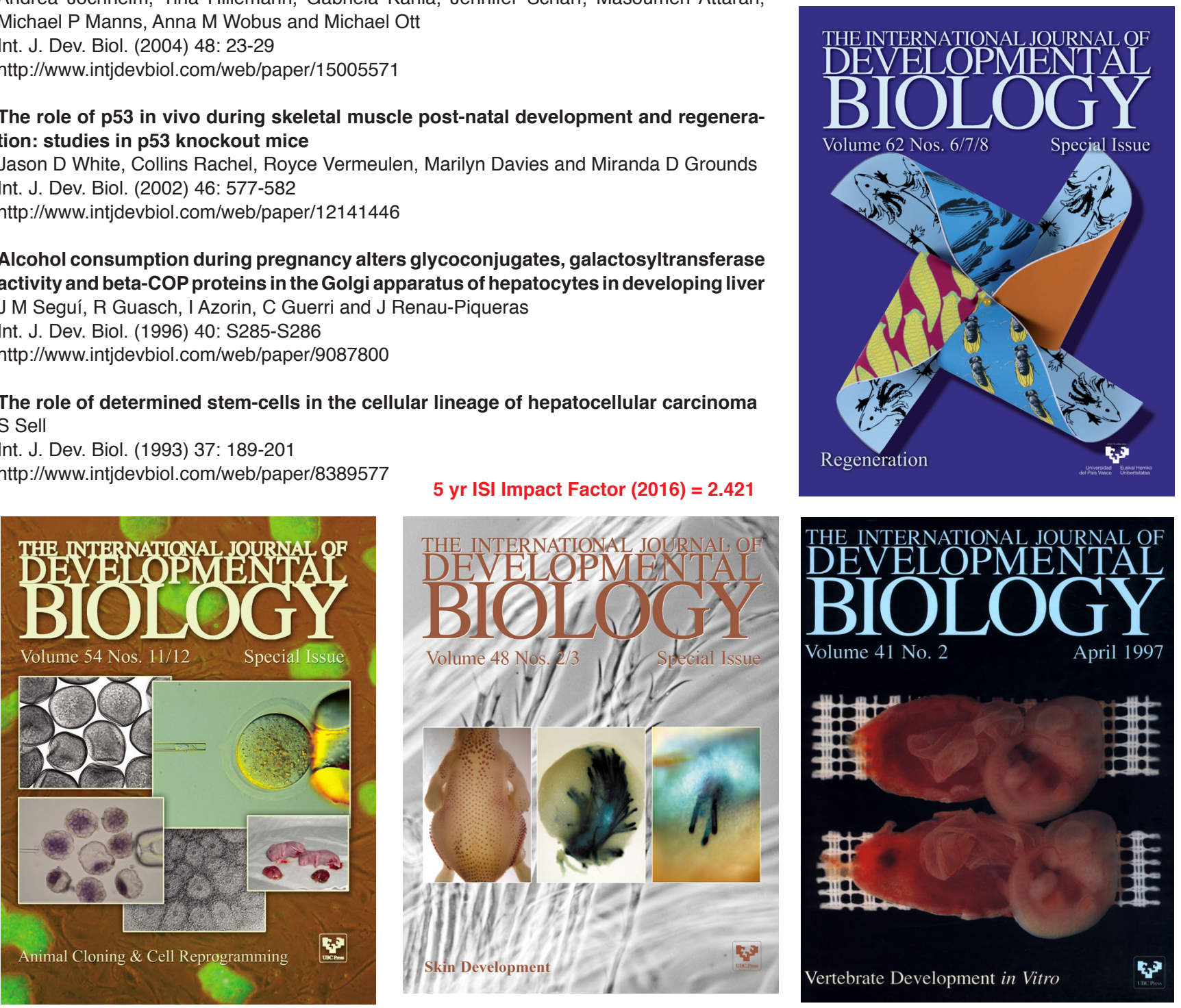

April 1997

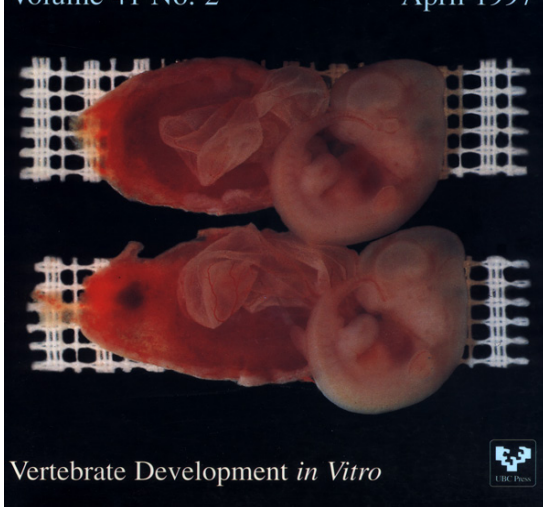

